\title{
CEO DUALITY, BOARD MONITORING, AND ACQUISITION PERFORMANCE: A TEST OF COMPETING THEORIES
}

\author{
Ashay Desai \\ University of Wisconsin-Oshkosh \\ Oshkosh, WI \\ Mark Kroll \\ Louisiana Tech University \\ Ruston, LA \\ Peter Wright \\ The University of Memphis \\ Memphis, TN
}

\begin{abstract}
Our paper presents an empirical examination of the relationship between $C E O$ duality and acquisition performance. Specifically, we address two related questions involving CEO duality under the auspices of agency and stewardship theories. The first involves the extent to which CEO duality directly influences the profitability of acquisitions. The second involves the influence of duality and the nature of outside board monitoring on acquisition performance. Our study tests competing hypotheses drawn from these two perspectives. We find that $C E O$ duality affects performance negatively and there is an important interaction effect between outside board monitoring and CEO duality.
\end{abstract}

Due to the increasing importance of corporate governance in organizations, there has been a growing body of research on the utility of CEO duality - particularly on the performance of firms that employ the dual structure. "CEO duality" refers to the situation where the same person serves simultaneously as CEO and chairperson of the board - a dual responsibility that has been subject to continuing debate. According to stewardship theory, such CEO duality establishes strong, unambiguous leadership, and shareholder interests are maximized by the shared incumbency (Chaganti, Mahajan, \& Sharma, 1985; Donaldson \& Davis, 1991; Finkelstein \& D'Aveni, 1994). Agency theorists argue such a leadership structure represents a conflict of interest, in that a CEO who is responsible for the overall management also is in a position to evaluate the effectiveness of that strategy (Jensen \& Meckling, 1976; Zajac \& Westphal, 1994).

Since these theoretical perspectives lead to opposing predictions on CEO duality, this study tests the direct and indirect performance effects of CEO duality, using arguments from both. A primary concern is whether CEO duality 
directly influences firm performance; i.e., whether there are differences in the financial performance of firms whose CEOs also serve as board chairpersons and firms that have separate individuals in those roles. Yet another issue is effective monitoring of CEOs by the board of directors when the CEO is chairperson of the board. Agency theorists suggest that boards of directors are a primary monitoring device protecting shareholder interests (Fama \& Jensen, 1983). Although boards are sometimes vigilant and exert significant influence on the organizations they oversee (Dalton \& Daily, 1998; Stiles, 2001), research shows that boards are not always effective stewards of organizational resources (Dalton, Daily, Ellstrand, \& Johnson, 1998; Donaldson, 1995). According to agency theory, duality promotes CEO entrenchment by challenging a board's ability to effectively monitor and discipline (Allan \& Widman, 2000; Dalton \& Daily, 1998). Stewardship theory contends that additional monitoring by outside (individuals who are not current or former employees of an organization) directors is superfluous. The nature of board monitoring contingent on the presence or absence of CEO duality also may impact the profitability.

Our paper examines the effects of CEO duality and outside director monitoring on profitability of acquisitions. While mergers and acquisitions are clearly on the rise, most deals do not create value. A study by Hayward and Hambrick (1997) examining why premiums above the market price often are paid to acquire another firm conclude that "CEO hubris" was an important factor in such overpayments. Related research does suggest that acquisitions are perhaps no better than break-even propositions for owners of acquiring firms (Morck, Shleifer, \& Vishny, 1990). Moreover, target firm managers have become more skilled at extracting higher prices for their firms (Bradley, Desai, \& Kim, 1988). If acquisitions are not ordinarily beneficial for the shareholders of acquiring companies, then why are they made? According to agency theory, many acquisitions are made because they benefit the senior executives. Indeed, top managers may pursue a variety of personal interests at the expense of stockholders. In support of this notion, Amihud and Lev (1981) describe managers' preferences for exaggerated firm size and diversity that are inconsistent with the profit maximization preferred by shareholders. Under agency theory, the abuse of stockholder interests may be increased in the presence of CEO duality. On the other hand, stewardship theory proposes that CEO duality facilitates effective action by the CEO.

The remainder of our paper is organized into several parts. First, we develop our hypotheses based on our review of the related literature. Next we specify our sample and methodology and present our findings. Finally, we discuss the results and their implications.

\section{Literature Review and Hypotheses}

In the related literature, firm monitoring, ownership control, managerial discretion and performance of corporate strategies have been studied (e.g., Dalton, Daily, Certo, \& Roengpitya, 2003; Hoskisson, Johnson, \& Moesel, 1994; 
Rechner, \& Dalton, 1991; Stiles, 2001). Agency theory has developed because an agency relationship is characteristic of the publicly held corporation. Inherent in an agency relationship is the separation between the management of a firm and its shareholders. With such separation, there will be some divergence between the agent's pursuit of self-serving strategies and policies that would enhance the welfare of the principal (Berle \& Means, 1932; Jensen \& Meckling, 1976). Because of this divergence in the pursuit of managerial interests versus owners' interests, monitoring managerial decisions becomes essential. Consequently, boards of directors have been authorized to monitor CEO decisions to assure that the interests of shareholders are protected.

Stewardship theory finds its roots in organizational theory, specifically in psychology and sociology (Boyd, 1995; Donaldson, 1990, Donaldson \& Davis, 1991), and suggests that there is no inherent conflict of interest or presence of opportunistic behavior. Specifically, CEO duality structures will help executives attain superior performance as the CEO exercises complete authority over the organization and his/her decisions are unambiguous. Such organizations enjoy the benefits of 'unity of direction' from an empowered leader. Unlike agency theory, the focus is on empowering structures and not on self-motivation of the CEO.

We expect differences in the profitability of acquisitions contingent on whether they are made to further the interests of stockholders or whether they are undertaken mainly to benefit the CEOs. The presumption of our work is that the profitability of acquisitions may be systematically different due to the presence (or absence) of CEO duality and the resulting interaction between CEO duality and board monitoring.

CEO duality. CEOs have higher structural power, stemming from their hierarchical position and relational power, based in expertise and prestige, than other organizational members and non-executive (outside) directors (Fama \& Jensen 1983, Stiles, 2001). As suggested earlier, CEO duality refers to a CEO who also serves as the chair of the board. Senior executives holding both positions achieve not only greater formal authority over board members, but also an increased informal influence over board processes (Allan \& Widman, 2000). Consequently, CEO duality has been criticized because it curtails monitoring effectiveness (Finkelstein \& D'Aveni, 1994; Zajac \& Westphal, 1994). A board controlled by the CEO, "signals the absence of separation of decision management and decision control..." (Fama \& Jensen 1983: 314). Since the chairperson of the board has the greatest influence over the actions of the board, the separation of decision management and decision control is compromised when a chairperson is also the CEO of the firm. Thus, requiring the chair and CEO positions to be held by different people will more effectively control the agency problems associated with the separation of ownership and control. Indeed, demands for reformation of corporate governance structures stress the importance of vigilant monitoring afforded by the absence of CEO duality (Lorsch \& MacIver, 1989). Stiles (2001: 647) suggests that "...chairman and 
CEO are two separate and differing roles." This is itself a good reason to keep these positions split. Given the significance of acquisitions and potential agency issues involved, under the auspices of agency theory, we expect that the CEO duality will be more likely to affect acquisition performance negatively.

\section{Hypothesis 1: The presence of CEO duality will be negatively associated with acquisition performance.}

Proponents of stewardship theory argue that constancy in leadership structure should have some advantages, as it allows for lucid delineation of leadership and control responsibilities that over time are well understood by management, board members, and the investors (Boyd, 1995; Daily \& Dalton, 1997). Donaldson and Davis (1991) and Mallette and Fowler (1992) show that the ROE returns to shareholders are improved by combining the role of the chair and CEO positions. Stewardship theory yields a contrasting hypothesis regarding acquisition performance. If it is true that CEO duality results in more consistent strategy formulation and implementation and subsequently superior firm performance, then the acquisition announcement effects should be positive. Table 1 shows a concise presentation of our hypotheses.

Hypothesis 1A: The presence of CEO duality will be positively associated with acquisition performance.

\section{Table 1}

\section{Hypothesized relationships between independent variables and acquisition performance (dependent variable).}

\begin{tabular}{llc}
\hline Variables & Agency Theory & Stewardship Theory \\
\hline $\begin{array}{l}\text { CEO Duality } \\
\begin{array}{l}\text { In absence of CEO duality } \\
\% \text { of outside board members } \\
\text { Outside board stock ownership }\end{array}\end{array}$ & $\begin{array}{c}\text { Negatively related (H2) } \\
\text { Hypothesis not offered }\end{array}$ & $\begin{array}{c}\text { Positively related (H2A) } \\
\text { Hypothesis not offered }\end{array}$ \\
$\begin{array}{l}\text { In presence of CEO duality } \\
\% \text { of outside board members } \\
\text { Outside board stock ownership }\end{array}$ & $\begin{array}{l}\text { Positively related (H3) } \\
\text { Positively related (H4) }\end{array}$ & $\begin{array}{c}\text { Hypothesis not offered } \\
\text { Negatively related (H4A) }\end{array}$ \\
\hline
\end{tabular}

\section{CEO Duality and Board Monitoring}

Previous studies have examined the beneficial and/or detrimental effects of CEO duality directly rather than duality's moderating effect on performance variables (e.g., Baliga, Moyer, \& Rao, 1996; Dahya \& Travlos, 2000; Finkelstein \& D'Aveni, 1994; Buchholtz, Young, \& Powell, 1998). Several studies (Baysinger \& Butler, 
1985; Gilson, 1990) show the importance of outside directors on performance associated with significant firm events. Other empirical evidence suggests that the presence of independent outside directors is in itself not adequate to ensure that acquisitions are undertaken in the shareholders' interests (Subrahmanyam, Rangan, Rosenstein, 1997). We argue that the presence or absence of CEO duality affects the role of the outside board of directors. Since the literature on effect of board monitoring on performance has been equivocal, studying board variables contingent on the presence or absence of CEO duality may provide further insights on the nature of board effectiveness. For our purpose, we are concerned with the impact of board monitoring on acquisition performance.

Percentage of outsiders. Theoretical support for the importance of board monitoring is based in agency theory (Jensen \& Meckling, 1976). According to this perspective, the function of boards is to reduce agency costs resulting from the delegation of strategic decision making, or "decision management," to top executives by exercising "decision control," which involves monitoring managerial decision making and performance (Fama \& Jensen, 1983: 303). In doing so, boards rely crucially upon outside directors, who are considered less likely than insiders to "collude with managers to expropriate residual claimants" (Fama \& Jensen, 1983: 315). The formal independence possessed by outsiders is assumed to permit more objective evaluation. Outside board members may pressure for improved corporate performance (Fama \& Jensen, 1983). For example, in situations of firm under-performance, CEO dismissal is more likely with more outsiders on the board (Weisbach, 1988). The implication is that outside board members may positively impact the profitability of firm acquisitions.

Other scholars have argued that inside board members (insiders) may enhance board effectiveness. For instance, Mizruchi (1983) contends that insiders compete with each other for succession to the position of CEO. Consequently, the insiders may be sensitive to appearing beholden to the CEO as they jockey for promotion, strengthening their resolve to control the behavior of the current CEO. Consistent with these works, Boyd (1994) finds that the percentage of insiders is positively associated with board monitoring. Baysinger and Butler (1985) suggest that outside directors serve primarily to exercise control and that inside directors are the main sources of advice on strategic issues. The implication of these contentions is that both outside and inside board members may positively affect the performance of corporate acquisitions.

Whether outsiders or insiders are positively or negatively associated with board effectiveness and acquisition performance, however, may be predicated on the presence or absence of CEO duality. Alternative governance mechanisms can substitute for each other, suggesting that either mechanism by itself can resolve agency problems (Rediker \& Seth, 1995; Walsh \& Seward, 1990). Rediker and Seth (1995) find that there is a substitutability effect for the various monitoring mechanisms, such that some firms may find it unnecessary to have a higher proportion of outsiders for monitoring purposes. 
Agency theory suggests that a CEO's position moderates the effects of board involvement on firm performance to the extent that absence of CEO duality can partially substitute for outside board of director monitoring as a solution to the agency problem (Jensen \& Meckling, 1976). Such settings should lessen the need for outside directors' monitoring activity, reducing the relationship between monitoring and performance. Moreover, in the absence of CEO duality, we expect the insiders to contribute to board effectiveness and firm performance. They may do so in subtle and in indirect ways so that their potential opposition to the decisions of the CEO may not be subject to documentation. For instance, possessing firm-specific knowledge, the insiders ostensibly may present both sides of issues, while carefully framing the alternatives in favor of one that may be opposed to the wishes of the CEO. Subtly promoting corporate performance and the interests of shareholders may establish the senior executives not only as valuable board members, but also as enlightened managers. In turn, the probability of their upward mobility (if not within the firm, then with external employment prospects) may be boosted (Stiles, 2001).

Thus, we expect the insiders to contribute to board effectiveness more in the absence of CEO duality, and we anticipate that insiders may detract from such effectiveness in the presence of CEO duality. The implication of these arguments is that, in the absence of CEO duality, a greater number of insiders would benefit a firm. In other words, using agency theory arguments, the percentage of outsiders may negatively impact the performance of acquisitions.

\section{Hypothesis 2: In the absence of CEO duality, the percentage of outside board members will be negatively associated with acquisition performance.}

Under the stewardship argument, absence of CEO duality results in diffused focus of long-term company objectives, and in a slower implementation of decisions. This is because in stewardship theory, pro-organizational and collectivist behaviors of managers provide greater utility (Mueller \& Barker, 1997; Dahya \& Travlos, 2000). Separating the CEO and board chair positions results in diffused information processing and discourages any decisive action by the CEO to the detriment of the firm's shareholders (Donaldson \& Davis, 1991; Daily and Dalton, 1997). In such situations, able outside directors through their network of external alliances, will benefit shareholders by offsetting the lack of unity of command. Therefore, the percentage of outsiders may be positively related to the performance of acquisitions by augmenting the insiders. This may significantly contribute to board effectiveness. Based on these arguments of stewardship theory, we offer the following hypothesis:

Hypothesis 2A: In the absence of CEO duality, the percentage of outside board members will be positively associated with acquisition performance. 
When the CEO is also the chair of the board, we argue, under the tenets of agency theory, that the inside board members may be reluctant to disagree with the CEO's pre-dispositions. That is because the CEO could determine the future career prospects as well as the monetary and non-monetary rewards of senior executives of the firm. Moreover, the CEO may have progressively approved the previous promotions of the senior managers to their present positions of authority. Axiomatically, it may be in the private interest of each executive to support the decisions of the CEO, particularly in his or her presence. Thus, we expect the insiders to promote the CEO's agenda while being ineffective monitors of corporate strategy in the presence of duality. In this setting, using arguments of agency theory, we expect the outsiders to contribute to CEO monitoring and corporate profitability.

Hypothesis 3: In the presence of $C E O$ duality, the percentage of outside board members will be positively associated with acquisition performance.

Stewardship theory suggests that managers are not motivated by self-interested behavior, but are effective stewards of organizations whose goals are consistent with those of the shareholders (Davis, Schoorman, \& Donaldson, 1997). In the presence of CEO duality, stewardship theory suggests that there are potential operational and strategic benefits associated with a higher proportion of insiders on corporate boards (Johnson, Hoskisson, \& Hitt, 1993). In such situations, enhanced commitment to the organization generated by full-time employment and coupled with intimate knowledge of relevant environments results in effective board-level decision making. Governance through outside directors would not provide additional effectiveness. Therefore, there would be less need for additional governance. This implies that from the stewardship theory point of view, in the presence of CEO duality, the percentage of outside board members may not be directly related to acquisition performance. Hence, we do not offer a hypothesis pertaining to this situation.

Outsider board stock ownership. In addition to the nature of board composition and CEO duality, the balance of power between the management and the board depends to a large extent on the board members' ownership stake. Empirical evidence suggests that agency costs may be reduced, either due to the introduction of financial incentives, or from relatively small levels of incentive alignment (Dalton et al., 2003; Rediker \& Seth, 1995; Zajac \& Westphal, 1994). Ownership plays a significant role as an incentive for outside board members to be responsive to the financial needs of shareholders (Hambrick \& Jackson, 2000), and motivates the outside board members to monitor corporate strategy responsibly and to promote firm performance. That is because, with enhanced director vigilance and corporate performance, these board members may witness an increase in the value of their own equity stakes in the firm. Consistent with this expectation, a number of empirical investigations have suggested that 
outside director ownership enhances board monitoring and appropriately motivates board members to pressure for corporate strategies that maximize firm value (Dalton et al., 1998; Johnson et al., 1993).

We submit that by increasing proportions of ownership in a firm outside board members will have a personal wealth incentive to monitor managers, in addition to their fiduciary responsibility as members of the board of directors. However outside board stock ownership's contribution to board effectiveness may be contingent on the presence or absence of CEO duality. Although enhanced board monitoring through ownership can help acquisition performance, if alternative governance mechanisms are operating properly, intervention by the outside board members may not be necessary, as the mechanisms can substitute for intervention (Dalton et al., 2003; Rediker \& Seth, 1995).

In the presence of CEO duality, consistent with the previous discussion under the auspices of agency theory, stock ownership may significantly motivate the outside board members to be more vigilant. That is because, in such a setting, the CEO may intervene to influence the nature of board monitoring. Inside board members may yield to the influence of their CEOs because they may be beholden to them. Thus, they often may be reluctant to oppose the CEO's wishes when the CEO is the chair of the board, personally witnessing board processes. As Donaldson explained, inside board members who persistently challenge the CEO "run the risk of finding themselves isolated and, in time, replaced" (1995: 100). Therefore, with CEO duality, our presumption is that the effect of inside board members on board effectiveness and firm performance may not be robust. Increasing ownership of outside directors, particularly in the presence of CEO duality, neutralizes the agency problem and increases the likelihood of contributing to acquisition performance. In such situations, an agency theory based hypothesis is:

Hypothesis 4: In the presence of CEO duality, outside board stock ownership will be positively associated with ac quisition performance.

While agency theory advocates that stock ownership can tip the balance of incentives, motivating outside directors to be more generous with their counsel and more vigilant in their monitoring (Hambrick, \& Jackson, 2000), stewardship theory suggests that managers (and directors) are motivated by the intrinsic satisfaction of their work rather than by extrinsic rewards (Davis et al, 1997). Stewardship theorists argue that empowering structures and mechanisms are not only appropriate but also sufficient to align principal-agent goals. A CEOs' proorganizational actions are best facilitated when the corporate governance structures give the $\mathrm{CEO}$ high authority and greater discretion. The resources that are necessary to guarantee pro-organizational behavior from an individualistic agent (i.e., monitoring and incentive costs) are diminished, because a steward is motivated to behave in ways that are consistent with organizational objectives. 
In other words, regardless of the presence or absence of CEO duality, additional financial incentives to outside directors are not required to monitor and encourage goal congruence. Indeed, additional control could prove to be counterproductive, as it may undermine the intrinsic pro-organizational behavior of the insiders. The following hypothesis is consonant with stewardship theory.

\section{Hypothesis 4A: In the presence of CEO duality, outside board stock ownership will be negatively associated with acquisition performance.}

In the absence of CEO duality, our conjecture is that inside board members may significantly contribute to board effectiveness and corporate performance. In such circumstances, the impact of outside director stock on board vigilance may be less robust. This implies that under agency theory tenets, in the absence of CEO duality, outside board equity stakes may not be directly related to acquisition performance. The stewardship explanation for the utility of financial incentives (as explained above) also indicates that such incentives to outside directors would not enhance acquisition performance. Manager's interests and utility motivations are directed to organizational rather than personal objectives. Hence, we do not offer an agency theory or stewardship theory based hypothesis pertaining to this situation (absence of CEO duality).

\section{Sample and Methodology}

\section{Sample}

We obtained a list of manufacturing firms (four-digit industry classifications ranging from 1000 to 4999 ) completing major acquisitions during the 1980 through mid-1990s period from various issues of the Almanac editions of Mergers and Acquisitions. We defined a major acquisition as one that increases the sales of the acquiring firm by at least 10 percent, as suggested by earlier research (Tosi \& Gomez-Mejia, 1989). The relative size of the acquisition is important, as only a major acquisition is likely to impact corporate value (Franks, Harris, \& Titman, 1991). Because we designed this study to use the event methodology, the announcement date of an acquisition had to be available from The Wall Street Journal Index. We obtained ownership and compensation data from company proxy reports. Only firms for which trading data were available from the CRSP database were included.

The sample consisted of firms that had not made other acquisitions during the year of their acquisition announcements. We used this criterion to ensure that outcomes associated with the announcements were not influenced by factors related to other acquisitions. Excluding corporations that are primarily in services is meant to ensure that differences unique to service firms would not impact the analysis (Bharadwaj \& Menon, 1993). Our sample consisted of 149 publicly traded corporations. At the time of the acquisition announcement, 47 of 
these firms did not have CEOs serving in both roles, while 102 firms did have CEOs serving in both roles

Variables included in the study. We assessed acquisition performance using cumulative abnormal returns (CARs) (Brown \& Warner, 1985). The percentage of outside board members was determined by the number of board members who were not employed (in any form) by the firm on whose board they served, divided by the total number of board seats. Outside board stock ownership represented the total number of each corporation's shares owned by its outside board members, divided by the total number of that firm's outstanding stock. The shareholding figures recorded for each director included all shares over which the director had voting power. These measures are consistent with those used by several researchers (Zahra, 1996; Hoskisson, Johnson, \& Moesel, 1994).

Finally, our control variables included CEO ownership/compensation ratio, size, and relatedness of acquisitions. Consistent with other works (e.g., Kerr \& Kren, 1992), we estimated each acquiring firm's CEO ownership by the value of his or her common stock on the day prior to the acquisition announcement. We valued stock options using a heuristic approach, which essentially values options as the difference between the option's exercise price and the underlying stock price at the time of the valuation (Lewellen, Loderer, \& Martin, 1987). The heuristic approach does not overstate option values, as options with exercise prices greater that the prevailing stock price are assigned no value (Kerr \& Kren, 1992). Compensation included the CEO's salary and bonus in the year of the acquisition announcement. The CEO ownership/compensation ratio was determined by dividing the value of CEO common stock and option holdings by the amount of CEO salary and bonus received. As a variable, this ratio controls for the incentive value of ownership, since CEO equity stakes of even less than five percent will have substantial incentive value in firms with large capitalizations (Ryan \& Wiggins, 2000).

We used sales in constant 1987 dollars as a proxy for size. We controlled for size because of its potential impact on acquisition performance (Franks et al., 1991 ) and for relatedness. We used a dummy variable (scored 0 if the acquirer and the target did not share the same two-digit SIC codes and 1 if they did) to represent relatedness. Some researchers contend that related diversification may enhance performance (Amihud \& Lev, 1981), while others suggest that unrelated acquisitions may contribute to high performance (Lubatkin, 1987; Walsh \& Seward, 1990).

Acquisition performance measurement. Since we assessed acquisition performance utilizing the event-study methodology (Brown \& Warner, 1985), we estimated cumulative abnormal returns (CARs) for each acquiring firm and for two event windows ( -1 to 0 and -3 to +3 days). We defined the event date (day 0 ) as the day prior to the first appearance of the acquisition announcement in The Wall Street Journal. This methodology has emerged as the dominant method for measuring the impact of various economically relevant events on the market value of corporations (Caves, 1989; Walsh \& Seward, 1990; Wright, Ferris, 
Hiller, \& Kroll, 1995). Caves argues that the event-study methodology is a "genuine innovation - - theoretically well-grounded, cheap to execute, and able to evade the problem of holding constant other factors that plague ex-post studies of mergers' effects. A better product, available at a lower price, naturally swept the intellectual marketplace" (1989: 151).

Model estimation procedures. To test Hypotheses 1 and $1 \mathrm{~A}$, we employed Cochran's t-tests to determine whether statistical differences in CARs existed between firms with CEO duality and those without. We performed t-tests for both event windows. In testing Hypotheses 2, 2A, 3, 4, and 4A, we employed a moderated cross-sectional regression analysis, in which acquisition performance (CARs) was regressed against the percent of outside board members, percent of stock owned by the outside board members, sales, relatedness, and the CEO ownership/compensation ratio. It is recognized that when a moderator variable $\mathrm{Z}$, upon which the form of association between $\mathrm{X}$ and $\mathrm{Y}$ is hypothesized to be contingent assumes only two values, regression equations should be estimated separately (Stone-Romero \& Anderson, 1994). In our study, the moderator variable is dichotomous - firms with CEO duality represent one group and the remaining firms without $\mathrm{CEO}$ duality comprise a second group.

\section{Results}

We present summary statistics and the correlation matrix for our data in Table 2 , and report the t-test results (Table 3 ) of differences between acquisition performance levels for firms with CEO duality and those without duality for both event windows. The results in Table 3 offer support for Hypothesis 1. Firms without CEO duality show positive CARs, while firms with duality demonstrate negative CARS. Hypothesis $1 \mathrm{~A}$ is not supported. Tables 4 and 5 present the regression results for the two event windows testing our remaining hypotheses.

While the percentage of outside board members is positively associated with acquisition performance in the presence of CEO duality, this ratio negatively impacts acquisition performance in its absence. These findings substantiate Hypotheses 2 and 3. In Hypothesis 4, we predicted that outside board stock ownership would be directly related to the performance of acquisitions in the presence of CEO duality. The findings support this hypothesis. We find no support for stewardship theory based Hypotheses $2 \mathrm{~A}$ and $4 \mathrm{~A}$. The results show that outside board stock ownership is positively related to acquisition performance in the absence of CEO duality as well. Our results suggest that size and relatedness in acquisitions are insignificantly associated with acquisition performance. CEO ownership/compensation ratio, however, is directly related to the performance of acquisitions.

\section{Discussion}

We examine the relationship between CEO duality and acquisition performance using agency and stewardship theoretical frameworks. Although agency 
Table 2

Summary Statistics and Correlation Matrix of Regression Models

\begin{tabular}{|c|c|c|c|c|c|c|c|}
\hline$\underline{\text { Variable }}$ & (1) & $(2)$ & (3) & (4) & $(5)$ & $(6)$ & $(7)$ \\
\hline (1) $\%$ of Outside Board Members & 1.000 & & & & & & \\
\hline (2) \% of Stock Owned by Outside Board Members & .241 & 1.000 & & & & & \\
\hline (3) CEO Ownership/Compensation Ratio & -.016 & .364 & 1.000 & & & & \\
\hline (4) Sales & .053 & -.127 & -.107 & 1.000 & & & \\
\hline (5) Related vs. Unrelated Acquisitions & .144 & .128 & .179 & .131 & 1.000 & & \\
\hline (6) Acquisition Performance (CARs days -1 to +1 ) & .421 & .382 & .315 & -.132 & .137 & 1.000 & \\
\hline (7) Acquisition Performance (CARs days -3 to +3 ) & .409 & .433 & .349 & -.148 & .119 & .878 & 1.000 \\
\hline Mean* & 45.92 & 5.61 & 10.54 & 8.75 & .65 & -.279 & -.555 \\
\hline Std. Dev. & 18.58 & 8.17 & 14.92 & 15.08 & - & 4.21 & 5.11 \\
\hline
\end{tabular}

$\mathrm{N}=149$; *All values are percentages except compensation, which is in 000's of 1987 dollars, and sales, which are in hundreds of millions of 1987 dollars. Related vs. Unrelated Acquisitions are scored as " 0 " if unrelated and "1" if related. 
Table 3

Cochran's T-Tests

\begin{tabular}{lccc}
\hline \multicolumn{3}{c}{ Means } \\
\hline & $\begin{array}{c}\text { With Duality } \\
(\mathbf{N}=\mathbf{1 0 2})\end{array}$ & $\begin{array}{c}\text { Without Duality } \\
(\mathbf{N}=\mathbf{4 7})\end{array}$ & T Scores \\
\hline CARs -1 to +1 & $-.740 \%$ & $2.263 \%$ & $2.89 *$ \\
CARs -3 to +3 & $-.176 \%$ & $1.414 \%$ & 1.68 \\
\hline
\end{tabular}

$\mathrm{p}<.10 * \mathrm{p}<05$

Table 4

Results of Regression Analyses: Acquisitions Performance

(CARS for -1 to +1 days)

\begin{tabular}{lcccc}
\hline & \multicolumn{2}{c}{ Without CEO Duality } & \multicolumn{2}{c}{ With CEO Duality } \\
\hline & $\begin{array}{c}\text { Parameter } \\
\text { Estimate }\end{array}$ & T Value & $\begin{array}{c}\text { Parameter } \\
\text { Estimate }\end{array}$ & T Value \\
\hline Intercept & -.062 & -.92 & -.003 & -.17 \\
\% of Outside Board Members & -.111 & $-1.98^{*}$ & .113 & $4.09^{* *}$ \\
\% of Stock Owned by & & & & \\
$\quad$ Outside Board Members & .249 & $2.11^{*}$ & .173 & $1.91^{*}$ \\
Sales & -.000053 & -1.28 & -.000013 & -1.34 \\
CEO Ownership/Compensation Ratio & .068 & $2.01^{*}$ & .0702 & $2.44^{*}$ \\
Related vs. Unrelated Acquisitions & .011 & 1.42 & .009 & 1.09 \\
$\mathrm{R}^{2}$ & .223 & & .199 & \\
F Value & 14.00 & & 10.32 & \\
$\mathrm{~N}$ & 47 & & 102 & \\
\hline
\end{tabular}

$\mathrm{p}<.05 * * \mathrm{p}<.05$

theory imparts the theoretical basis for a greater part of research conducted in corporate governance (Dalton et al., 2003), alternative explanations must be considered for examining such relationships. It should be noted that theories differ significantly in their assessment of the effectiveness of CEO duality and of outside directors in performing their duties (Daily \& Dalton, 1997; Kosnik, 1987). Stewardship theory provides a framework that presumes that managers are seeking to maximize organizational performance and suggests a positive role for CEO duality and considers the monitoring role of outside directors unnecessary. Within the context of agency theory, outside directors are seen as providing more independent, shareholder-interested monitoring (Daily \& Johnson, 1997; Dalton \& Rechner, 1989). Notably, in line with the competing theoretical research dedicated to CEO duality and outside directors, the empirical literature provides no consensus on the effects of these on performance (Daily \& Dalton, 1997). 
Table 5

Results of Regression Analyses: Acquisitions Performance

(CARS for $-\mathbf{3}$ to +3 days)

\begin{tabular}{lcccc}
\hline & \multicolumn{2}{c}{ Without CEO Duality } & \multicolumn{2}{c}{ With CEO Duality } \\
\hline & $\begin{array}{c}\text { Parameter } \\
\text { Estimate }\end{array}$ & T Value & $\begin{array}{c}\text { Parameter } \\
\text { Estimate }\end{array}$ & T Value \\
\hline Intercept & .092 & 1.01 & .099 & 1.47 \\
\% of Outside Board Members & -.172 & $-2.04^{*}$ & .392 & $3.13^{* *}$ \\
\% of Stock Owned by & & & & \\
$\quad$ Outside Board Members & .495 & $2.18^{*}$ & .669 & $1.85^{*}$ \\
Sales & -.000050 & -1.29 & -.000068 & -1.12 \\
CEO Ownership/Compensation Ratio & .094 & $2.02^{*}$ & .084 & $2.38^{*}$ \\
Related vs. Unrelated Acquisitions & .018 & 1.31 & .012 & 1.60 \\
$\mathrm{R}^{2}$ & .2157 & & .231 & \\
F Value & 8.36 & & 9.31 & \\
$\mathrm{~N}$ & 47 & & 102 & \\
\hline
\end{tabular}

$p<.05^{* *} p<.05$

We find evidence supporting the notion that CEO duality structure intensifies the agency problem. Contrary to the arguments of stewardship theory, having an independent chair leads to gains in shareholder wealth. Specifically, our results are consistent with the premise that CEO duality may negatively impact the profitability of acquisitions in firms. Additionally, we find that the relationship between leadership structure and shareholder benefit is contingent on board monitoring. Although splitting the position of chairperson and CEO helps acquisition performance in general, a number of board variables may affect acquisition performance differently, depending on the presence or absence of CEO duality in firms. These include both the percentage of outside board members and outside board stock ownership.

In line with the agency theory perspective on CEO duality, duality is related to board vigilance. The findings relating to select board variables are qualitatively different, depending on the presence or absence of CEO duality. For instance, the percentage of outside board members is negatively associated with acquisition performance in the absence of CEO duality, while outsiders are positively related to performance in the presence of duality. This provides additional support for the assertions of agency theory that, in the absence of duality, less monitoring is required by the outside directors. We add new evidence to the debate on the substitution-monitoring hypothesis (governance arrangements as substitutes on one another). This finding is particularly important since it implies that a focus on various elements in the corporate governance-firm performance nexus is likely to lead to considerable increase in performance. 


\section{Limitations, Implications and Conclusions}

Some limitations of the study should be acknowledged. Other governance mechanisms exist. Our paper does not include the role of institutional and blockholder ownership. Given their equity positions, institutional investors could affect the relationship between CEO duality and performance. Future studies could investigate the role of ownership structure as a moderator between the CEO duality and outside director relationship. Our paper focuses on acquisition as a performance variable. Numerous other performance variables can be included to study the combined effects of CEO duality and performance.

The scope of this study is in a specific context, but our discussion of the results leads us to a number of conclusions and implications. Independent leadership structure (separating CEO and chairperson of the board roles) is more beneficial for acquisition performance. In the presence of CEO duality, monitoring through the outside board of directors, and incentive alignment through compensation contracts are other ways to ensure owner-interested action. 80\% of U.S. public companies combine the jobs of CEO and chair (Daily \& Dalton, 1997; Allan \& Widman, 2000). Only a small minority of corporations in the United States has installed an outside director as chairperson, but the practice has long been common in other countries (Allan \& Widman, 2000). Do the inherent conflicts of interests and the intimidating power of a CEO duality position manifest themselves in acquisition performance? From our finding, it appears to be so. Recent concerns about the dual role of a CEO may be justifiable and need serious consideration. Our study supports the counsel of those who call for the elimination of CEO duality as one way to enhance firm governance and performance. These views have been included in the Cadbury Committee Report (1992) in the U.K. and by the conference Board in the U.S.A. (Dahya \& Travlos, 2000). The obvious implication is that CEO duality should be discouraged, and the demand for responsible corporate governance could be forwarded through shareholder or governmentally imposed measures.

Lorsch and Maclver (1989) suggest CEO duality has power that primarily impedes outside directors from exercising their authority. Our study shows that a larger percentage of outside directors, in the presence of duality, contribute more towards performance. Consequently, we conclude that the probability of board members effectively protecting the interests of shareholders is boosted if outsiders are more numerous on the boards of firms with CEO duality. The implication may be that more outsiders should be recruited to serve on these boards. Moreover, consistent with the results, it may be recommended that such board members be granted stock ownership in the firm, while limiting their level of compensation. On the other hand, possessing firm-specific knowledge, the insiders can play a positive role, but evidently more so in the absence of CEO duality. The suggestion is that in the presence of duality, assuring that a majority of board members are outsiders is prudent to ensure that acquisitions are properly aligned with the goals of the firm's shareholders. In the absence of duality, 
however, agency problems may be less, and inside directors who know the company and markets might be more valuable than outside directors. It may be advisable to have inside members comprise the majority of board membership in such firms.

Our findings suggest that not only is outside board ownership positively related to acquisition firm performance in the presence of CEO duality, such ownership is also associated with performance in the absence of duality. One interpretation of this relationship is that stock ownership affects director behavior, not because of the direct financial incentive, but because of the increased psychological bond to the corporation (Lorsch \& MacIver, 1989; Hambrick \& Jackson, 2000). This can motivate outside directors to be more liberal with their advice and more vigilant in their monitoring, regardless of duality structure. The implication is that granting outside board stock ownership may be advantageous regardless of the state of CEO duality. Granting equity stakes to outside board members may not be costly and apparently has substantial benefits.

In conclusion, CEO duality may be a negative attribute, detracting from effective board monitoring and profitable corporate strategies. Forming effective boards may be subject to specificities at the firm level of analysis rather than to broadly based generalities. Given the importance of acquisitions in particular and corporate performance in general, we are hopeful that further theoretical advancement and empirical studies using multiple perspectives are likely to be fruitful.

\section{References}

Allan, P. \& Widman, A. (2000). A comparison of the views of CEOs and public pension funds on the corporate governance issues of chairman-CEO duality and election of lead directors. American Business Review, 18 (1), 49-55.

Amihud, Y. \& Lev, B. (1981). Risk reduction as a managerial motive for conglomerate mergers. Bell Journal of Economics, 12, 605-617.

Baliga, B., Moyer, R., \& Rao, R. (1996). CEO duality and firm performance: What's the fuss? Strategic Management Journal, 17, 41-53.

Baysinger, B. \& Butler, H. (1985). Corporate governance and the board of directors: Performance effects of changes in board composition. Journal of Law, Economics. and Organization, 1, 101-124.

Berle, A. \& Means, G. (1932). The modern corporation and private property. New York: Macmillan.

Bharadwaj, S. G. \& Menon. A. (1993). Determinants of success in service industries: A PIMS-based empirical investigation. Journal of Services Marketing, 7 (4), 19-40. 
Boyd, B. (1994). Board control and CEO compensation. Strategic Management Journal. $15,335-344$.

Boyd, B. (1995). CEO duality and firm performance: A contingency model. Strategic Management Journal, 16 (4), 301-312.

Bradley, M., Desai, A., \& Kim, E. (1988). Synergistic gains from corporate acquisitions and their division between the stockholders of target and acquiring firms. Journal of Financial Economics, 21, 3-40.

Brown, S. \& Warner, J. (1985). Measuring security price performance. Journal of Financial Economics, 8, 205-258.

Buchholtz, A., Young, M., \& Powell, G. (1998). Are board members pawns or watchdogs? The link between CEO pay and firm performance. Group and Organization Management, 23 (1), 6-26.

Cadbury, Sir A. (1992). Committee on financial aspects of corporate governance, (HMSO).

Caves, R. (1989). Mergers, takeovers, and economic efficiency. International Journal of Industrial Organization, 7, 151-174.

Chaganti, R., Mahajan, V., \& Sharma, S. (1985). Corporate board size, composition and corporate failures in retailing industry. Journal of Management Studies, 22, 400417.

Dahya, J. \& Travlos, N. (2000). Does one man show pay? Theory and evidence on the dual CEO revisited. European Financial Management, 6 ( 1), 85-99.

Daily, C. \& Dalton, D. (1997). CEO and board chair roles held jointly or separately: Much ado about nothing?. The Academy of Management Executive. 11 (3), 11-21.

Daily, C. \& Johnson, J. (1997). Sources of CEO power and firm financial performance: A longitudinal assessment. Journal of Management, 23 (2), 97-117.

Dalton, D. \& Daily, C. (1998). Corporate governance digest. Business Horizons, 4l (2), 6-8.

Dalton, D., Daily, C., Certo, S., \& Roengpitya, R. (2003). Meta-analysis of financial performance and equity: Fusion or confusion? Academy of Management Journal, $\underline{46}(1), 13-26$.

Dalton, D., Daily, C., Ellstrand, A., \& Johnson J. (1998). Meta-analytic reviews of board composition, leadership structure and financial performance. Strategic Management Journal, 19, 269-290. 
Dalton, D. \& Rechner P. (1989). On the antecedents of corporate severance agreements: An empirical assessment. Journal of Business Ethics, 8, 455-462.

Davis, J., Schoorman, F., \& Donaldson, L. (1997). Toward a stewardship theory of management. Academy of Management Review, 22, 20-47.

Donaldson, G. (1995). A new tool for boards: The strategic audit. Harvard Business Review, 73 (4), 99-107.

Donaldson, L. (1990). The ethereal hand: Organizational economics and management theory. Academy of Management Review, 15, 369-381.

Donaldson, L. \& Davis, J. (1991). Stewardship theory or Agency theory: CEO governance and shareholder returns. Australian Journal of Management, 16 ( I), 49-64.

Fama, E. \& Jensen, M. (1983). Separation of ownership and control. Journal of Law and Economics, 26, 301-325.

Finkelstein, S. \& D'Aveni, R. (1994). CEO duality as a double-edged sword: How boards of directors balance entrenchment avoidance and unity of command. Academy of Management Journal. 37, 1079-1108.

Franks, J., Harris, R., \& Titman, S. (1991). The postmerger share-price performance of acquiring firms. Journal of Financial Economics, 29, 81-96.

Gilson, S. C. (1990). Bankruptcy, boards, banks and blockholders. Journal of Financial Economics, 27 (2), 355-387.

Hambrick, D. \& Jackson, E., (2000). Outside directors with a stake: The linchpin in improving Governance. California Management Review, 42 (4), 108-128.

Hayward, M. \& Hambrick, D. (1997). Explaining the premium paid for large acquisitions: Evidence of CEO hubris. Administrative Science Quarterly, 42, 103-127.

Hoskisson, R., Johnson, R., \& Moesel, D. (1994). Corporate divestiture intensity in restructuring firms: Effects of governance, strategy, and performance.Academy of Management Journal, 37, 1207-1251.

Jensen, M. \& Meckling, W. (1976). Theory of the firm: Managerial behavior, agency costs, and ownership structure. Journal of Financial Economics, 3, 305-360.

Johnson, R., Hoskisson, R., \& Hitt, M. (1993). Board of director involvement in restructuring: The effects of board versus managerial controls and characteristics. Strategic Management Journal, 14, 33-50.

Kerr, J. \& Kren, L. (1992). Effect of relative decision monitoring on chief executive compensation. Academy of Management Journal, 35 (2), 370-397. 
Kosnik, R. D. (1987). Greenmail: A study of board performance in corporate governance. Administrative Science Quarterly, 32, 163-185.

Lewellen, W., Loderer, C., \& Martin, K. (1987). Executive compensation and executive incentive problems: An empirical analysis. Journal of Accounting and Economics, 9(3), 287-310.

Lorsch, J. W. \& MacIver, E. (1989). Pawns or potentates: The reality of America's corporate boards. Boston: Harvard Business School Press.

Lubatkin, M. (1987). Merger strategies and stockholder value. Strategic Management Journal, $8,39-53$.

Mallette, P. \& Fowler, K. L. (1992). Effects of board composition and stock ownership on the adoption of "poison pills". Academy of Management Journal, 35, 10101035 .

Mizruchi, M., (1983). Who controls whom? An examination of the relation between management and boards in large corporations. Academy of Management Review, 8 , 426-435.

Morck, R., Shleifer, A., \& Vishny, R. (1990). Do managerial motives drive bad acquisitions? Journal of Finance, 45, 31-48.

Mueller, G. \& Barker, V. (1997). Upper echelons and board characteristics of turnaround and non turnaround firms declining firms. Journal of Business Research, 39, 119 134.

Rechner, P. L. \& Dalton, D. R. (1991). CEO duality and organizational performance: A longitudinal analysis. Strategic Management Journal. 12, 155-160.

Rediker, K. \& Seth, A. (1995). Boards of directors and substitution effects of alternate governance mechanisms. Strategic Management Journal, 16, 85-99.

Ryan, H. \& Wiggins R. (2000). Differences in the compensation structures of the CEO and other senior managers. The Journal of Business and Economic Studies, 6 (2), 22-39.

Stiles, P. (2001). The impact of board on strategy: An empirical examination. Journal of Management Studies, 38 (5), 627-650.

Stone-Romero, E. \& Anderson, L. (1994). Relative power of moderated multiple regression and the comparison of subgroup correlation coefficients for detecting moderating effects. Journal of Applied Psychology, 74, 3-10.

Subrahmanyam, V., Rangan, N., \& Rosenstein, S. (1997). The role of outside directors in bank acquisitions, Financial Management, 26 (3), 23-36. 
Tosi, H. L. \& Gomez-Mejia, L. R. (1989). The decoupling of CEO pay and performance: An agency theory perspective. Administrative Science Quarterly, 34, 169-189.

Walsh, J. P. \& Seward, J. K. (1990). On the efficiency of internal and external corporate control mechanisms. Academy of Management Review, 15, 421-458.

Weisbach, M. (1988). Outside directors and CEO turnover. Journal of Financial Economics, 20, 431-460.

Wright, P., Ferris, S., Hiller, J., \& Kroll, M. (1995). Competitiveness through management of diversity: Effects on stock price valuation. Academy of Management Journal, 38, 272-287.

Zahra, S. (1996). Governance, ownership, and corporate entrepreneurship: The moderating impact of industry technological opportunities. Academy of Management Journal, 39 (6), 1713-1736.

Zajac, E. \& Westphal, J. (1994). The costs and benefits of managerial incentives and monitoring in large U.S. corporations: When is more not better? Strategic Management Journal, 15, 121-142.

Ashay Desai is Assistant Professor of Management in the College of Business at The University of Wisconsin-Oshkosh. He received his Ph.D. from the University of Memphis. His current research interests include Corporate governance and declining firms, competitiveness, and turnaround strategies.

Mark Kroll is Head of the Management and Marketing Department and the Maurice Tatum Professor of Business Administration at Louisiana Tech University. He received his DBA degree from Mississippi State University. His research interests include agency theory, corporate governance, and strategic leadership.

Peter Wright is Professor of Management and the holder of the University of Memphis Endowed Chair in Free Enterprise Management. He received his undergraduate degree from Ohio State University, and his M.B.A. and Ph.D. degrees from Louisiana State University. His research focuses on agency theory and the valuation of firm strategies. 